\title{
Intraspinal Neurenteric Cysts in Children
}

\author{
Chunquan Cai, Changhong Shen, Weidong Yang, Qingjiang Zhang, Xiaoli Hu
}

\begin{abstract}
Background: Neurenteric cysts are rare congenital epithelium-lined cysts of the central nervous system. They are found predominantly in the spinal cord, with lower incidence in the intracranial compartment, and may be associated with various other congenital spinal anomalies. Seven patients with symptomatic intraspinal neurenteric cysts are presented. Materials and Methods: Seven patients with intraspinal neurenteric cysts aged from nine months to ten years treated at this hospital from May 2000 to July 2006 were reviewed. The clinical manifestations, imaging and surgical findings of patients were analyzed retrospectively. All patients underwent operation. One patient's cervical neurenteric cyst was resected using the lateral cervical approach, and the other six resections were performed with posterior approach. Results: All seven patients presented with neurological involvement. One patient had an intramedullary cyst, while the other six cysts were situated ventrally. Three patients' cysts occurred in the cervical region, two in the cervicothoracic region, one in the thoracic region and one in the lumbar region. One patient had bony anomalies, and one had a lumbar posterior occult spinal dysraphism. Five patients' symptoms improved rapidly after surgery. Conclusions: Intraspinal neurenteric cysts in children are rare and most occur ventral to the spinal cord. Magnetic resonance imaging (MRI) is the most effective imaging modality. Earlier diagnosis and surgical resection of spinal neurenteric cysts improves prognosis.
\end{abstract}

RÉSUMÉ: Kystes neuroentériques intraspinaux chez les enfants. Contexte : Les kystes neuroentériques sont des kystes congénitaux rares qui sont tapissés d'épithélium et localisés dans le système nerveux central. On les retrouve surtout au niveau de la moelle épinière et moins fréquemment au niveau intracrânien. Ils peuvent être associés à différentes anomalies spinales congénitales. Matériel et méthodes : Nous révisons les observations concernant sept patients porteurs d'un kyste neuroentérique intraspinal symptomatique, âgés de 9 mois à 10 ans, traités dans notre centre hospitalier entre mai 2000 et juillet 2006. Nous analysons rétrospectivement les manifestations cliniques, l'imagerie et les constatations chirurgicales chez ces patients. Tous les patients ont été opérés. Chez un patient, le kyste neuroentérique cervical a été enlevé par une approche cervicale latérale et chez les six autres par une approche postérieure. Résultats : Les sept patients ont consulté pour des troubles neurologiques. Un patient avait un kyste intramédullaire et les six autres un kyste situé antérieurement. Le kyste était situé à la région cervicale chez trois patients, à la région cervicothoracique chez deux, à la région thoracique chez un et à la région lombaire chez l'autre. Un patient présentait des anomalies osseuses et un patient présentait un dysraphisme spinal occulte à la région lombaire postérieure. Chez cinq patients les symptômes se sont améliorés rapidement après la chirurgie. Conclusions : Les kystes neuroentériques intraspinaux sont rares chez les enfants et la plupart sont situés à la région antérieure de la moelle épinière. L'IRM est la meilleure technique d'imagerie chez ces patients. Le pronostic est meilleur si le diagnostic et l'ablation chirurgicale sont plus précoces.

Can. J. Neurol. Sci. 2008; 35: 609-615

Neurenteric cysts are rare congenital cysts of the central nervous system first described by Puusepp in $1934 .{ }^{1}$ Most are spinal with few intracranial examples. ${ }^{2}$ Intraspinal neurenteric cysts are commonly located in the cervical and thoracic region, in rare cases they are found at the craniovertebral junction, lumbar and sacral regions. ${ }^{3-7}$ They are lined by intestinal epithelium. They are characterized histologically by an abundance of mucin-producing goblet cells and an intermittently ciliated epithelial layer. ${ }^{1}$ Although histologically benign, they can bring about major neurological deficits if detection and treatment are delayed. The spinal neurenteric cysts may be associated with various other congenital spinal anomalies. ${ }^{8}$ Here, we present seven cases of neurenteric cysts, and attempt to put forward a useful strategy for the diagnosis and treatment of neurenteric cysts along with a review of the literature.

\section{Patients And Methods}

\section{Patients' Details}

Seven cases of intraspinal neurenteric cysts managed surgically at the department of pediatric neurosurgery of Tianjin Children's Hospital and General Hospital of Tianjin Medical University between May 2000 and July 2006 are reported here.

Table 1 shows the age, sex, clinical symptoms, neurological

From the Department of Neurosurgery (CC, CS, WY), General Hospital of Tianjin Medical University; Department of Pediatric Neurosurgery (CC, QZ), Department of Pathology

(XH), Tianjin Children's Hospital, Tianjin, P. R. China.

Received October 12, 2007. Final Revisions Submitted April 18, 2008.

Correspondence to: Changhong Shen, Department of Neurosurgery, General Hospital of Tianjin Medical University, No. 54, Anshan Road, Heping District, Tianjin 300052, P. R. China. 
deficits, radiological findings, operative findings and outcome of these patients. There were four males and three females, with ages ranging from nine months to ten years. They had varying degrees of neurological involvement as showed in Table 1.

\section{METHODS}

\section{Imaging Details}

All patients underwent MRI screening, six patients for the clinical suspicion of cord compression lesion and one for the suspicion of atlantoaxial dislocation (Case 2). Two patients under went CT screening of the spine, and one underwent plain $\mathrm{X}$-ray of the spine. No multiple neurenteric cysts were found in our series. One patient had an intramedullary cyst (Case 4), and the other six cysts were situated ventrally. Three patients' cysts occurred in the cervical region (Figure 1), two in the cervicothoracic region (Figure 2-A, B, C, D), one in the thoracic region and the other one in the lumbar region. One patient in our series had bony anomalies (hemivertebra and scoliosis) (Figure 3 ), and one had a lumbar posterior occult spinal dysraphism (Figure 4). The MR imaging characteristics of the cyst contents were isointense to CSF in all sequence in five patients of our series, and two appeared hyperintense to CSF on both $\mathrm{T}_{1}$ and $\mathrm{T}_{2}$ weighted images. None of the four cysts that underwent additional contrast administration showed gadolinium enhancement.

\section{Surgical Methods}

Two types of surgical approach were used in our patients.

One patient's cervical neurenteric cyst was resected using the lateral cervical approach (Case 2). Careful dissection and mobilization of the sternocleidomastoid and accessory nerve was performed. The underlying fat and lymphatics were cleaned away to expose the muscular attachments to the lateral cervical spine. These muscular attachments were divided and exposure of the lateral cervical spine was obtained. Bone was removed and the dura was opened. The spinal cord was flattened and displaced dorsally. Complete resection of the lesion was achieved and then the spinal cord was pulsated.

The other patients with cervical neurenteric cysts in cervicothoracic region, thoracic and lumbar regions were operated upon using the traditional approach (posterior approach). Laminectomy was performed at the region of the spine involved. The dura was noted to be very tight; after opening the dura, avoiding the spinal cord and nerve roots, the cyst was noted in front of the of the spinal cord in the six patients

Table 1: Summary of patients' characteristics

\begin{tabular}{|c|c|c|c|c|c|c|c|c|c|c|}
\hline Case & Age/sex & Site & $\begin{array}{l}\text { Presentation } \\
\text { duration }\end{array}$ & $\begin{array}{l}\text { Neurological } \\
\text { findings }\end{array}$ & $\begin{array}{l}\text { Image } \\
\text { findings }\end{array}$ & $\begin{array}{l}\text { Associated } \\
\text { anomaly }\end{array}$ & Approach & $\begin{array}{l}\text { Operative } \\
\text { findings }\end{array}$ & Outcome & $\begin{array}{l}\text { Follow- } \\
\text { up } \\
\text { duration } \\
\end{array}$ \\
\hline 1 & $\begin{array}{l}13 \\
\mathrm{~ms} / \mathrm{M}\end{array}$ & $\begin{array}{l}\mathrm{L}_{3}-\mathrm{L}_{4} \\
\text { Ventral }\end{array}$ & $\begin{array}{l}\text { Decreased movement } \\
\text { of LL for } 6 \mathrm{~ms} \text {, } \\
\text { urinary incontinence } \\
\text { since birth }\end{array}$ & $\begin{array}{l}\text { Decreased muscle bulk } \\
\text { and hypotonia in both } \\
\text { LL, decreased } \\
\text { movement in both LL, } \\
\text { power } 0-1 / 5 \text {, } \\
\text { absent plantar reflex }\end{array}$ & $\begin{array}{l}\text { Intradural } \\
\text { extramedullary } \\
\text { oval cyst, } \\
\text { isointense to } \\
\text { CSF }\end{array}$ & $\begin{array}{l}\text { Malformed } \\
\mathrm{L}_{1}-\mathrm{L}_{5} \\
\text { bodies } \\
\text { of vertebra }\end{array}$ & $\begin{array}{l}\text { Posterior } \\
\text { approach, } \\
\text { laminectomy } \\
\mathrm{L}_{3}-\mathrm{L}_{4}\end{array}$ & $\begin{array}{l}\text { Spinal cord pulsation } \\
\text { absent, complete excision }\end{array}$ & $\begin{array}{l}\text { Minimal } \\
\text { improvement in } \\
\text { LL, power } 1-2 / 5, \\
\text { no change in } \\
\text { urinary } \\
\text { incontinence }\end{array}$ & $3 \mathrm{yrs}$ \\
\hline 2 & $\begin{array}{l}4.5 \\
\mathrm{yrs} / \mathrm{F}\end{array}$ & $\begin{array}{l}\mathrm{C}_{2}-\mathrm{C}_{3} \\
\text { Ventral }\end{array}$ & $\begin{array}{l}\text { Neck tilt to left } \\
\text { and neck pain } \\
\text { radiating to arms } \\
\text { for } 1 \mathrm{~m}\end{array}$ & $\begin{array}{l}\text { Mild wasting of the } \\
\text { cervical paraspinal } \\
\text { muscles and weakness } \\
\text { of all limbs }\end{array}$ & $\begin{array}{l}\text { Intradural } \\
\text { extramedullary } \\
\text { round cyst, } \\
\text { isointense to CSF }\end{array}$ & $\begin{array}{l}\text { No bony } \\
\text { anomaly }\end{array}$ & $\begin{array}{l}\text { Lateral } \\
\text { cervical } \\
\text { approach }\end{array}$ & $\begin{array}{l}\text { Spinal cord was flattened, } \\
\text { thin and displaced } \\
\text { dorsally, } \\
\text { complete excision }\end{array}$ & $\begin{array}{l}\text { Very minimal } \\
\text { torticollis, } \\
\text { neurologically } \\
\text { normal }\end{array}$ & $1 \mathrm{yr}$ \\
\hline 3 & $9 \mathrm{~ms} / \mathrm{F}$ & \begin{tabular}{|l|}
$\mathrm{C}_{3}-\mathrm{C}_{4}$ \\
Ventral
\end{tabular} & $\begin{array}{l}\text { Neck stiff for } 15 \\
\text { days, quadriplegia } \\
\text { for } 9 \text { days }\end{array}$ & $\begin{array}{l}\text { Stiff neck, } \\
\text { weakness } \\
\text { of all limbs } \\
\text { power } 2 / 5\end{array}$ & $\begin{array}{l}\text { Intradural } \\
\text { extramedullary } \\
\text { round cyst, } \\
\text { hyperintense } \\
\text { to CSF }\end{array}$ & $\begin{array}{l}\text { Hemivert- } \\
\text { ebra and } \\
\text { scoliosis }\end{array}$ & $\begin{array}{l}\text { Posterior } \\
\text { approach, } \\
\text { laminectomy } \\
\mathrm{C}_{2}-\mathrm{C}_{4}\end{array}$ & $\begin{array}{l}\text { Spinal cord was flattened, } \\
\text { complete excision the cyst } \\
\text { wall after needle } \\
\text { aspiration, the cyst fluid } \\
\text { was clear }\end{array}$ & $\begin{array}{l}\text { Neurologically } \\
\text { normal, } \\
\text { hemivertebra } \\
\text { and scoliosis } \\
\text { are untreated }\end{array}$ & $9 \mathrm{~ms}$ \\
\hline 4 & $3 \mathrm{yrs} / \mathrm{F}$ & \begin{tabular}{|l|}
$\mathrm{C}_{7}-\mathrm{T}_{1}$ \\
Intra- \\
medullary
\end{tabular} & $\begin{array}{l}\text { Pyrexia for } 6 \mathrm{~ms}, \\
\text { paraplegia for } 25 \\
\text { days, back pain } \\
\text { for } 20 \text { days and } \\
\text { sphincter } \\
\text { incontinence for } 15 \\
\text { days }\end{array}$ & $\begin{array}{l}\text { Hypotonia in } \\
\text { both LL, } \\
\text { power } 0 / 5 \text {, } \\
\text { absent plantar reflex }\end{array}$ & $\begin{array}{l}\text { Intramedullary } \\
\text { round cyst, } \\
\text { isointense to } \\
\text { CSF }\end{array}$ & $\begin{array}{l}\text { No bony } \\
\text { anomaly }\end{array}$ & $\begin{array}{l}\text { Posterior } \\
\text { approach, } \\
\text { laminectomy } \\
\mathrm{C}_{6}-\mathrm{T}_{1}\end{array}$ & $\begin{array}{l}\text { Spinal cord wide, } \\
\text { incomplete excision of } \\
\text { the cyst wall (mostly) } \\
\text { after needle aspiration, } \\
\text { the cyst fluid was } \\
\text { clear and yellowy }\end{array}$ & $\begin{array}{l}\text { Evidently } \\
\text { improvement } \\
\text { in LL, power } 3 / 5 \text {, } \\
\text { minimal } \\
\text { improvement } \\
\text { in sphincter } \\
\text { incontinence }\end{array}$ & 5 yrs \\
\hline 5 & $\begin{array}{l}10 \\
\mathrm{yrs} / \mathrm{M}\end{array}$ & $\begin{array}{l}\mathrm{C}_{6}-\mathrm{T}_{2} \\
\text { Ventral }\end{array}$ & $\begin{array}{l}\text { Weakness of both } \\
\text { LL for } 1 \mathrm{~m} \text {, back pain } \\
\text { for } 15 \text { days and } \\
\text { sphincter } \\
\text { incontinence for } 4 \\
\text { days }\end{array}$ & $\begin{array}{l}\text { Hypotonia in } \\
\text { both LL, } \\
\text { power } 3 / 5, \\
\text { weak plantar reflex }\end{array}$ & $\begin{array}{l}\text { Intradural } \\
\text { extramedullary } \\
\text { oval cyst, } \\
\text { hyperintense to } \\
\text { CSF }\end{array}$ & $\begin{array}{l}\text { No bony } \\
\text { anomaly }\end{array}$ & $\begin{array}{l}\text { Posterior } \\
\text { approach, } \\
\text { laminectomy } \\
\mathrm{C}_{5}-\mathrm{T}_{2}\end{array}$ & $\begin{array}{l}\text { Spinal cord was flattened, } \\
\text { thin and displaced } \\
\text { dorsally, incomplete } \\
\text { excision the cyst wall } \\
\text { (mostly) after needle } \\
\text { aspiration, the cyst fluid } \\
\text { was clear and yellowy }\end{array}$ & $\begin{array}{l}\text { Neurologically } \\
\text { normal }\end{array}$ & $13 \mathrm{~ms}$ \\
\hline 6 & $2 \mathrm{yrs} / \mathrm{M}$ & $\begin{array}{l}\mathrm{C}_{2}-\mathrm{C}_{6} \\
\text { Ventral }\end{array}$ & $\begin{array}{l}\text { Neck pain for } 2 \mathrm{~ms} \text {, } \\
\text { quadriplegia and } \\
\text { urinary incontinence } \\
\text { for } 3 \text { days }\end{array}$ & $\begin{array}{l}\text { Stiff neck }( \pm) \text {, } \\
\text { hypotonia in all limbs, } \\
\text { UL's power } 2-3 / 5 \text {, } \\
\text { LL's power } 3-4 / 5\end{array}$ & $\begin{array}{l}\text { Intradural } \\
\text { extramedullary } \\
\text { oval cyst, } \\
\text { isointense to CSF }\end{array}$ & $\begin{array}{l}\text { No bony } \\
\text { anomaly }\end{array}$ & $\begin{array}{l}\text { Posterior } \\
\text { approach, } \\
\text { laminectomy } \\
\mathrm{C}_{2}-\mathrm{C}_{5}\end{array}$ & $\begin{array}{l}\text { Spinal cord was flattened, } \\
\text { complete excision the cyst } \\
\text { wall after needle } \\
\text { aspiration, the cyst fluid } \\
\text { was clear }\end{array}$ & $\begin{array}{l}\text { Neurologically } \\
\text { normal }\end{array}$ & $9 \mathrm{~ms}$ \\
\hline 7 & $5 \mathrm{yrs} / \mathrm{M}$ & \begin{tabular}{|l|}
$T_{7}$ \\
Ventral
\end{tabular} & $\begin{array}{l}\text { Asymmetric } \\
\text { weakness } \\
\text { of LL for } 21 \text { days }\end{array}$ & $\begin{array}{l}\text { Hypotonia in both LL, } \\
\text { right power } 3 / 5, \text { left } \\
\text { power } 4 / 5 \text {, weak } \\
\text { plantar reflex }\end{array}$ & $\begin{array}{l}\text { Intradural } \\
\text { extramedullary } \\
\text { round cyst, } \\
\text { isointense to CSF }\end{array}$ & $\begin{array}{l}\text { No bony } \\
\text { anomaly }\end{array}$ & $\begin{array}{l}\text { Posterior } \\
\text { approach, } \\
\text { laminectomy } \\
\mathrm{C}_{2}-\mathrm{C}_{5}\end{array}$ & $\begin{array}{l}\text { Spinal cord was slightly } \\
\text { flattened, complete } \\
\text { excision }\end{array}$ & $\begin{array}{l}\text { Neurologically } \\
\text { normal }\end{array}$ & $5 \mathrm{~ms}$ \\
\hline
\end{tabular}

m, month; yr, year; M, Male; F, Female; LL, lower limbs; UL, upper limbs; CSF, cerebrospinal fluid 


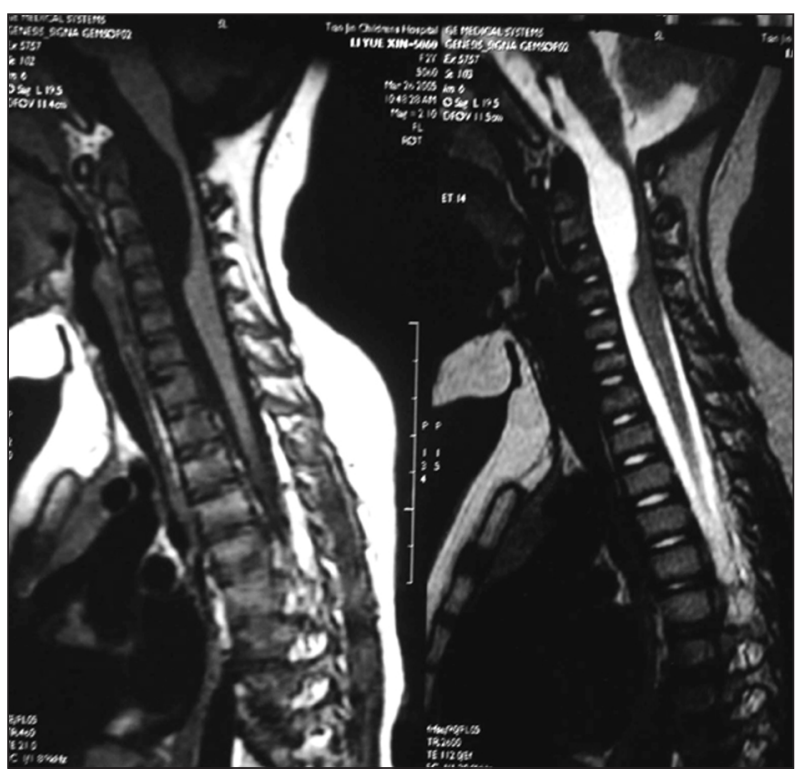

Figure 1: Sagittal MR $T_{1}$-weighted and $T_{2}$-weighted images showing an intradural extramedullary cystic lesion in the ventral side of the cervical spinal cord at the $C_{2}-C_{6}$ level and the compression of the spinal cord (Case 6).

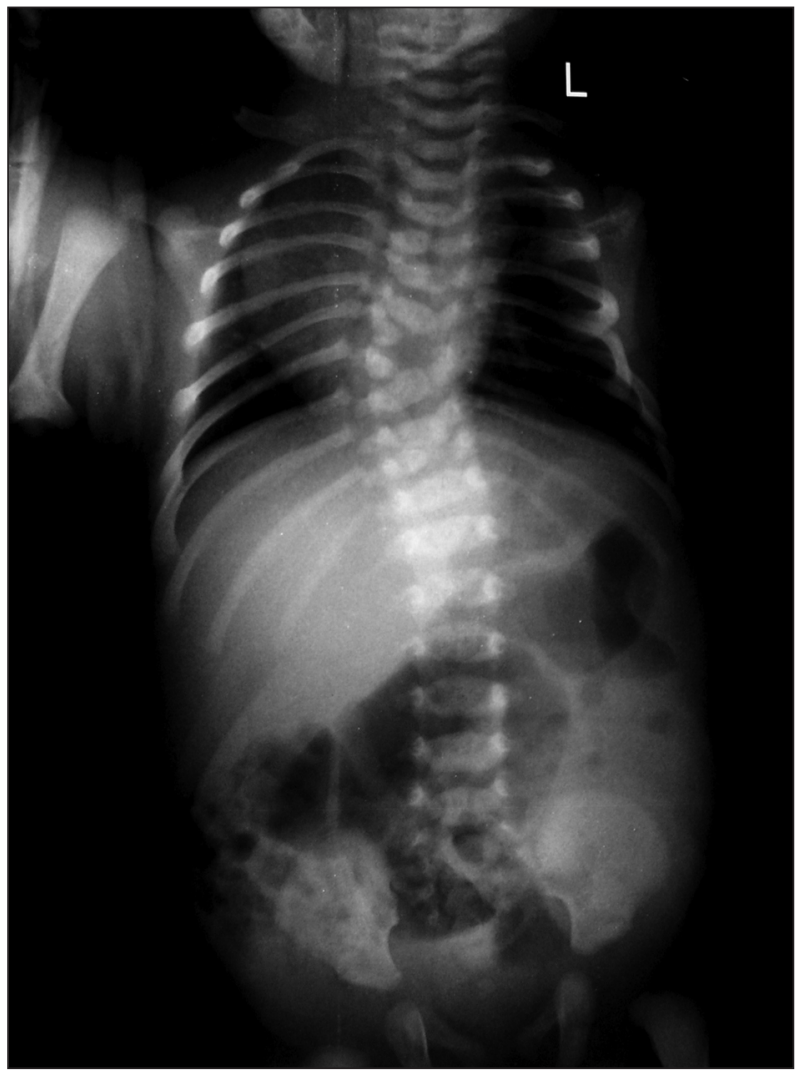

Figure 3: Plain X-ray of the spine showing bony anomalieshemivertebra and scoliosis (Case 3).
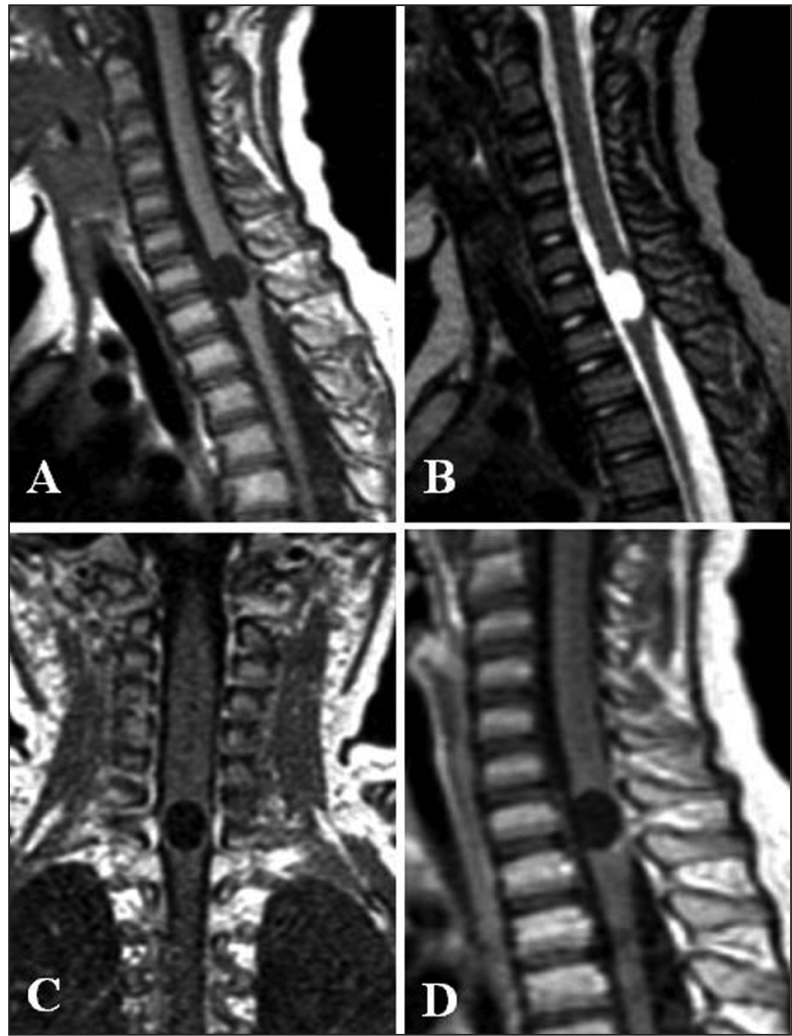

Figure 2: Sagittal $M R T_{1}$-weighted and $T_{2}$-weighted images showing an intramedullary cystic lesion at the $C_{6}-T_{1}$ level $(2 A, B)$. Coronal MR $T_{1}$-weighted image showing an intramedullary cystic lesion at the $C_{6}-T_{1}$ level $(2 C)$. Sagittal $M R T_{1}$-weighted image showing no enhancement of the lesion (2 D) (Case 4).

having ventral cysts. Three of the cysts were completely resected (Figure 5), for two cysts the wall was total resected and in the other one, (Case 5), most of the cyst wall was excised after needle aspiration of the cyst contents (its color was from clear to yellow); the pulsations of the spinal cord could be seen. In the patient with an intramedullary neurenteric cyst (Case 4), after opened the dura, we found a widened spinal cord without adhesion to the arachnoid membrane. A $6 \mathrm{~mm}$ midline myelotomy was performed at the wide portion. The cyst fluid was clear and yellowy. The cyst wall was almost totally removed. Adequate communication was created between the "bed" of the cyst and the subarachnoid space. After the resection, the pulsations of the spinal cord could be seen immediately.

\section{RESULTS}

\section{Histopathology Findings}

The tissue removed at surgery was fixed in $10 \%$ buffered formalin. Sections were routinely processed and embedded in paraffin; Five micron sections were cut and stained with hematoxylin and eosin $(\mathrm{H} \& \mathrm{E}, \times 100)$. The histopathology of all seven excised cysts showed a simple columnar or cuboidal epithelium resting on delicate fibrovascular tissue (Figure 6, 7). 


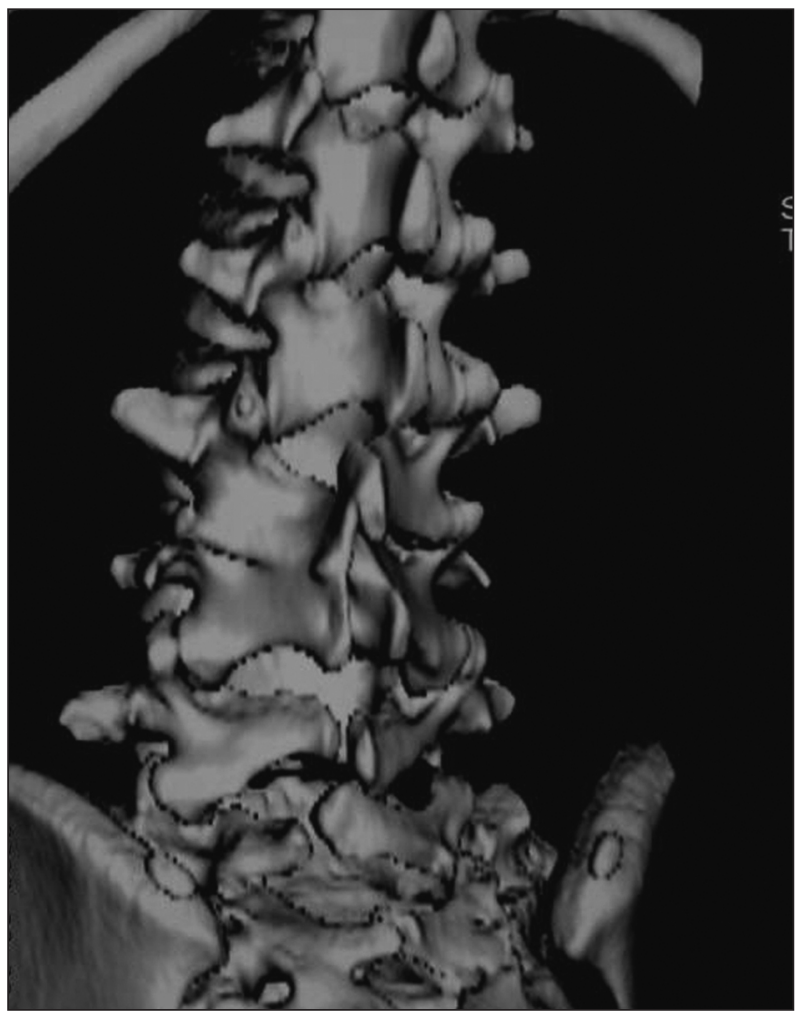

Figure 4: Three-dimentional spiral CT reconstruction of the spinal column showing a lumbar posterior occult spianl dysraphism (Case 1).

Both mucin-producing goblet cells and ciliated cells were present in four (Case 2, 3, $5 \& 7$ ) of the seven patients. Three cases (Case 1, 4 \& 6) had mucin-producing goblet cells with no ciliated cells. Epithelium was basically columnar; however, cuboidal cells were also present in three cases (Case 1, 4 \& 5), which might be the result of chronic pressure. In Cases 3 and 4, foci of chronic inflammatory cell infiltrates were present. No case showed squamous metaplasia. No cyst had gross or microscopic hemorrhage. Table 2 shows the details of patients' histopathological findings.

\section{OUTCOME AND FOLLOW-UP}

As summarized in Table 1, except in two cases (Case $1 \& 4$ ), the outcome after surgical treatment was excellent. There was no surgical mortality. Motor weakness disappeared or improved more rapidly in the younger patients with shorter duration of symptoms. Four patients whose complaints were back or neck pain showed obviously relief from one day to three days after surgery. Five patients had no complaints, and their neurological functioning was normal from two months to six months after surgery. All patients also underwent MRI screening after surgery; postoperative MRI showed the absence of cysts and decompressed spinal cord (Figure 8).

The patients were followed up for six months to five years (average 21 months). There was no clinical or radiological evidence of recurrence in any of the seven patients. Five were

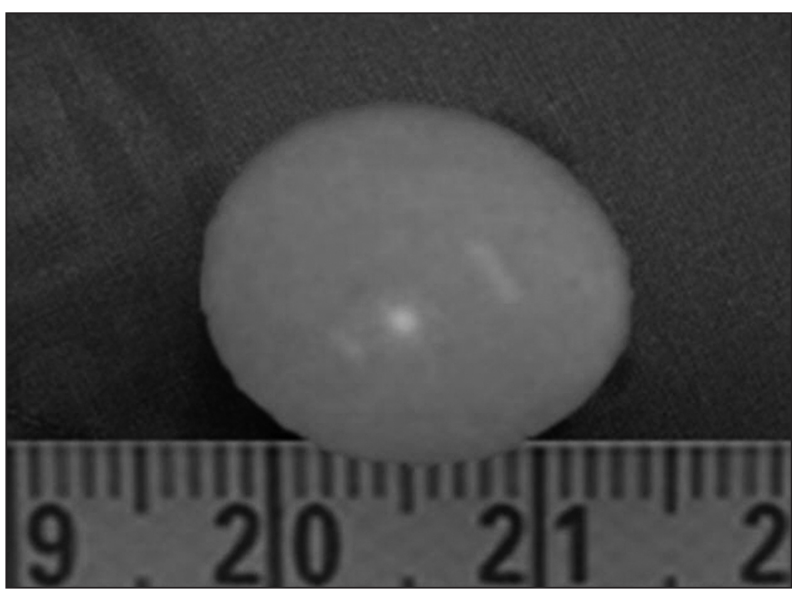

Figure 5: A completely resected cyst showing milky white contents (Case 7).

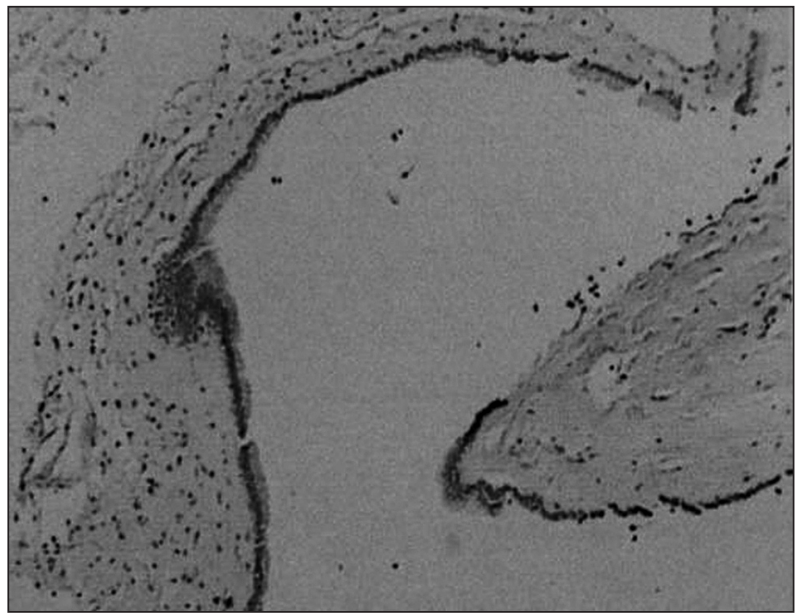

Figure 6: Histological examination of a neurenteric cyst wall showing a simple epithelium resting on a delicate fibrovascular tissue $(H \& E, \times 100)$.

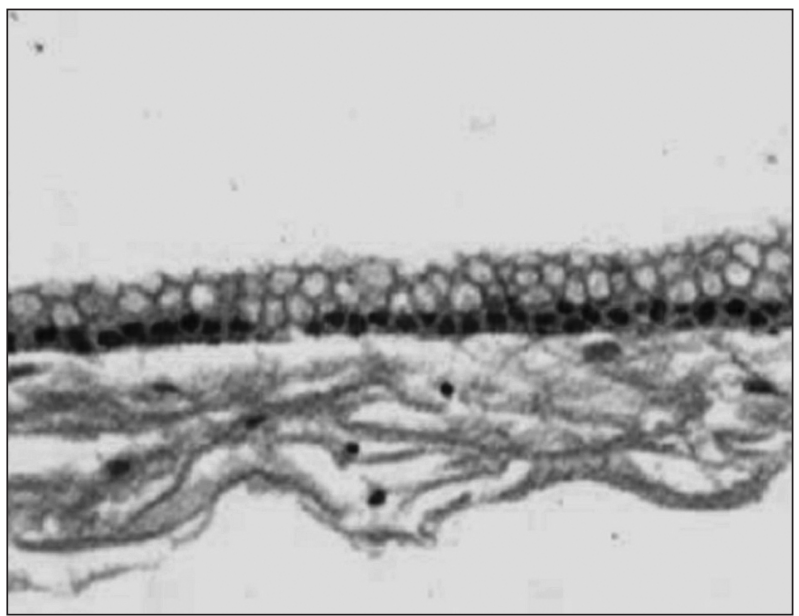

Figure 7: Histological examination of a neurenteric cyst wall showing simple columnar to cuboidal epithelium rich in mucinproducing cells $(H \& E, \times 400)$. 
Table 2: Summary of patients' histopathological findings

\begin{tabular}{c|l|c|c}
\hline Case & \multicolumn{1}{|c|}{ Histopathology } & Mucin & Cilia \\
\hline 1 & Columnar to cuboidal; mucin-producing cell rich & + & - \\
\hline 2 & Columnar, ciliated; mucin-producing cell rich & + & + \\
\hline 3 & $\begin{array}{l}\text { Columnar, ciliated; mucin-producing cell rich; } \\
\text { focal chronic inflammation in stroma }\end{array}$ & + & + \\
\hline 4 & $\begin{array}{l}\text { Cuboidal; mucin-producing cell poor; focal } \\
\text { chronic inflammation in stroma }\end{array}$ & \pm & - \\
\hline 5 & $\begin{array}{l}\text { Columnar to cuboidal, ciliated; mucin-producing } \\
\text { cell poor }\end{array}$ & \pm & + \\
\hline 6 & Cuboidal; mucin-producing cell rich & + & - \\
\hline 7 & Columnar, ciliated; mucin-producing cell rich & + & + \\
\hline
\end{tabular}

neurological normal. Patient 1, who presented with the most longstanding signs and symptoms and Patient 4 who had an intramedullary lesion with symptoms dating back 25 days remained neurologically impaired.

\section{Discussion}

Neurenteric cysts are most commonly encountered in the posterior mediastinum. ${ }^{9}$ They are rarely present in relation to the central nervous system. Intraspinal neurenteric cysts are congenital malformations derived from endodermal inclusions within the spinal. ${ }^{10}$ Various hypotheses have been proposed to explain the embryogenesis of neurenteric cysts: ${ }^{3,10-13}$ the persistence of the neurenteric canal or formation of an accessory neurenteric canal; the split notochord syndrome; over distension of the neural tube; a teratomatous origin from primordial germ cell and aberrant vascular supply to the developing neural tissue. One recent theory suggests that this condition cannot be explained as arrest in a stage of development or failure of regression of an embryonic structure, because there is no communication between the enteric tract and the neural tube during normal ontogenesis. ${ }^{14}$ The precise pathogenesis of the neurenteric cysts is unknown. They comprise $0.7-1.3 \%$ of all spinal cord tumors. ${ }^{10,15}$ Males predominate over females in a ratio of 2.6-3.2. ${ }^{9}$ In our series, the male to female ratio was 4:3. Spinal neurenteric cysts commonly manifest during the second and third decades of life. ${ }^{16}$ However, they can manifest soon after birth or during the neonatal period if they are associated with severe cardiopulmonary abnormalities ${ }^{17}$ The youngest patient of our series was nine-months-old. In rare cases, they may remain latent until the seventh decades of life. ${ }^{16}$ Neurenteric cysts of the central nervous system have been found anywhere from the supratentorial compartment to the coccyx. More than half of reported spinal neurenteric cysts occurred in the cervical region, ${ }^{15}$ and the remaining cases are almost equally distributed between thoracic and thoracolumbar junctions. Cysts are rarely at the craniovertebral junction or lumbosacral region. ${ }^{15,16}$ Most of the neurenteric cysts are extramedullary and fewer than $5 \%$ of all neurenteric cysts are situated in the intramedullary compartment. ${ }^{9,16,18}$ Most of the spinal neurenteric cysts are situated ventrally. ${ }^{9,19}$ In our series, no dorsally located cyst was

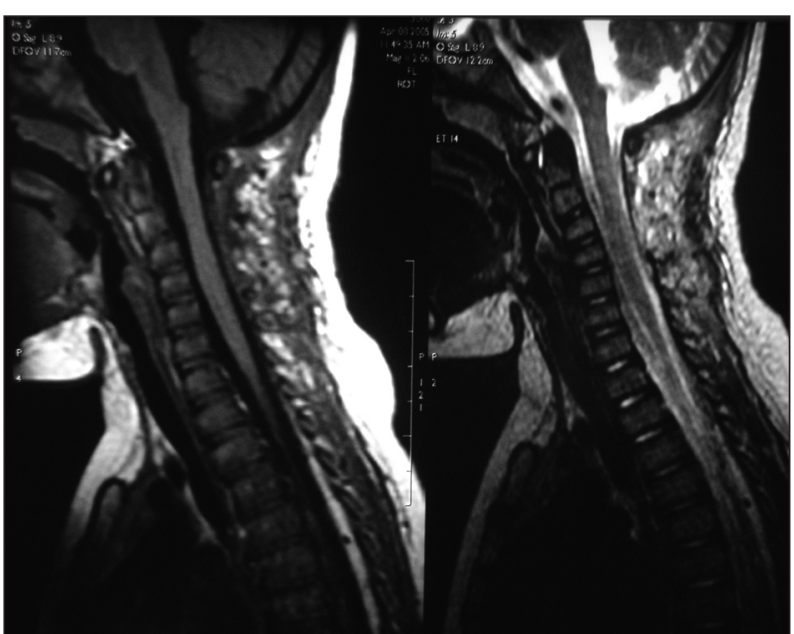

Figure 8: Post-operative MRI showing the absence of the lesion and decompression of the spinal cord (Case 6).

found, and very few cases of dorsally situated neurenteric cysts have been reported.$^{20,21}$ Reports of multiple neurenteric cysts are rare. Vinters et $\mathrm{al}^{22}$ and Oyama et $\mathrm{al}^{23}$ reported multiple neurenteric cysts in the posterior fossa and/or spinal canal respectively, but no cases of multiple neurenteric cysts were found in our series.

In the majority of patients, the signs and symptoms are the results of the compression of the spinal cord and/or nerve root, and most of these patients present with progressive symptoms..$^{3,9,24}$ Of all symptoms, pain was the most frequent symptom of spinal neurenteric cysts. Pain can either be local or radicular. ${ }^{1}$ For four (4/7) patients in our series, the main complaints were neck or back pain. In our series, motor weakness was also a frequent symptom. All seven patients of our series were brought to our hospital due to neurological deficits arising from spinal cord compression (including decreased movement or paraplegia of the affected limbs, quadriplegia, sphincter-incontinence). Pyrexia was found as the initial symptom in one case (Case 4) of our series. According to Kadhim, ${ }^{17}$ fever is attributed to degenerative changes in the neurenteric cyst, triggering inflammatory cell infiltration and tumor necrosis factor secretion. So pyrexia is a rare presenting symptom of neurological deficit. In rare cases, spontaneous rupture of the cyst and spilling of the contents into the cerebrospinal fluid caused severe arachnoiditis. ${ }^{25}$ Bacterial meningitis can also occur secondary to bacterial infection of the cyst. ${ }^{26}$ In some cases, the signs and symptoms have a fluctuating course, mimicking inflammatory diseases such as multiple sclerosis. ${ }^{22}$ Intraspinal neurenteric cysts may occur in isolation without any bony spinal abnormalities as is shown in five of our cases. On the other hand, other authors have shown that neurenteric cysts are associated with bony anomalies in $50 \%$ of cases, and plain films can be useful in the detection of these additional defects. ${ }^{27,28}$ Bony anomalies can occur as part of a more complex malformation with spinal dysraphism. These bony anomalies include blocked vertebra, hemivertebra, scoliosis, 
split cord malformation, Kovalesky's canal, Klippel-Feil anomaly and butterfly vertebra. ${ }^{9,12,19,21,27}$

Magnetic resonance imaging was the first line of investigation in our patients presenting with spinal cord and/or nerve root compression, and all seven patients in our series underwent MRI screening. On MRI, neurenteric cysts are predominantly situated anterior to the cord in the extrmedullary plane. Neurenteric cysts have been described to be isointense relative to CSF in all sequences in five patients of our series, and two appeared hyperintense to CSF on both T1 and T2 weighted images. These signal characteristics are thought to correlate with high protein content or hemorrhage within the cyst.${ }^{19}$ Hayashi et $\mathrm{al}^{29}$ were able to demonstrate the relationship between cyst protein concentration and signal intensity relative to white matter on MRI. Thus, the various imaging characteristics of the same pathology can be explained by different protein content of cyst fluid. Most of the cases can be diagnosed preoperatively with an MRI scan. The associated bony abnormalities are better delineated on a CT. On the other hand, MRI scan not only provides accurate information regarding morphology of the lesion but any associated cord change can be identified.

Though neurenteric cysts are typically epithelium-lined cysts, they have been described to have variable appearances on light microscopy, as reflected by the many names that have been used to describe them. ${ }^{21,30}$ Wilkins and Odom ${ }^{31}$ classified neurenteric cysts into three types. Type I: single pseudostratifed, cuboidal or columnar epithelium with or without cilia lying on a basement membrane; Type II: similar to type with addition of mucous glands, serous glands, smooth muscle, fat, cartilage, bone, elastic fibres, lymphoid tissue or nerve ganglion. Type III: similar to type II with addition of ependymal or glial tissue. According to this classification, the histopathological results of all the cases we reported belong to type I.

Neurenteric cysts should be considered in the differential diagnosis when vertebral developmental abnormalities are present in associated with an intraspinal cyst mass. One patient in our series had bony anomalies (hemivertebra and scoliosis). Arachnoid cysts have to be considered in the differential diagnosis of such a cystic lesion, as arachnoid cysts are usually situated posterior to the cord and are usually not associated with bony anomalies. One patient in our series had an intramedullary cyst. This is an unusual location, but the differential diagnosis of such neurenteric cysts (intramedullary) includes ependymal cysts, cystic tumors, hemangioblastomas, syrinx, epidermoid and dermoid. With the typical clinical manifestation of the compression of the spinal cord and/or nerve root and the help of newer diagnostic modalities (CT and MRI) most of the patients with intraspinal neurenteric cyst can be diagnosed preoperatively.

The treatment of choice for intraspinal neurenteric cyst is surgical removal of the cyst. One should aim for total excision during operation (including total resection of the cyst wall after needle aspiration of the cyst contents). Simple aspiration of the cyst has no role in treatment, as this maneuver usually leads to recurrence.$^{32}$ However, aggressive removal of a ventrally located cyst through a posterior approach may result in spinal cord injury. Ventrally located intradural cysts such as arachnoid cysts, epithelial cysts, or ependymal cysts are frequently not amenable to complete resection without undue manipulation of the cord, in which case wide fenestration into the subarachnoid space is an acceptable alternative and is generally curative. Most intraspinal neurenteric cysts are located in the extramedullary plane, with a clear plane of dissection between the lesion and the neural elements. ${ }^{16}$ In such cases, complete resection can be achieved. However, this is not always the case, because the contents of the cysts are irritants and cause adhesions when released into the subarachnoid space. This can create difficulty and prevent complete excision. Five cysts in our series underwent total excision, but total excision of the other two cysts (Case 4 \& 5) was not possible because of the involvement of the vital neural structures. Intramedullary cysts are usually known to have no clear plane of cleavage between the spinal cord and the cyst wall, ${ }^{16}$ and complete removal is difficult. In Case 4 , a $6 \mathrm{~mm}$ midline myelotomy was performed at the wide portion. Adequate communication was created between the "bed" of the cyst and the subarachnoid space after resecting the cyst. Following this the patient was disease free at five years follow-up. The major difficulty in this operation was establishing adequate communication between the "bed" of the cyst and the subarachnoid space. Posterior approach to resect a ventral intradural lesion is difficult, especially if the lesion is located in the upper cervical spine. In Case 2, a lateral approach to the cyst was performed. This approach is safe and relatively straightforward, and resulted in no cervical instability.

Recurrence has rarely been reported in the literature. The recurrence rate was $37 \%$ in the series by Chavda et al, ${ }^{32}$ and the interval between the initial surgery and recurrence was 4-14 years. In contrast, Kim et $\mathrm{al}^{3}$ reported no recurrence in any of their eight patients during a mean period of 38 months. Similarly, Holmes et $\mathrm{al}^{12}$ noticed recurrence in only 1 of 26 patients. No recurrence occurred in any of our seven patients during a mean period of 21 months. The improvement of neurological symptoms and signs is greatly dependent upon the age of the patient, the duration of the symptoms and the degree of preexisting medullary damage. ${ }^{33}$ Except in two case (Case 1 \& 4), the outcome after surgical treatment was excellent. Case 1 in our series had had urinary incontinence since birth, and hence, not much improvement was expected in a follow-up of three years; however, the patient's lower limbs showed minimal improve-ment after surgery. Case 4 in our series is a patient with an intramedullary cyst; she had sphincter-incontinence for 15 days, and only had minimal improvement after surgery. We think it because she had more serious preexisting medullary damage than others.

In conclusion, although intraspinal neurenteric cysts are congenital lesions, they are usually not detected until after the neurological symptoms have manifested. Magnetic resonance imaging should be the first line of investigation and an effective method for imaging screening. All patients should be operated on as soon as possible after diagnosis, and an attempt should be made to completely excise the cyst (including total resection of the cyst wall after needle aspiration of the cyst contents). Clinicoradiological follow-up is required to evaluate the recurrence and long-term outcome.

\section{ACKNOWLEDGEMENTS}

The authors thank Prof. Ouyan Shi, Tianjin Medical University, for her constructive advice and Dr. Chunxiang Wang, 
Tianjin Children's Hospital, for his assistance with reproduction of photographic images. No financial support was received for the preparation of this paper.

\section{REFERENCES}

1. Puusepp M. Variété rare de tératome sousdural de la région cervicale (intestinome): quadriplégie, extirpation, guérison complète. Rev Neurol. 1934; 2: 879-86.

2. Paleologos TS, Thom M, Thomas DG. Spinal neurenteric cysts without associated malformations. Are they the same as those presenting in spinal dysraphism? Brit J Neurosurg. 2000; 14 (3): 185-94.

3. Kim CY, Wang KC, Choe G, Kim HJ, Jung HW, Kim IO, et al. Neurenteric cyst: its various presentations. Childs Nerv Syst. 1999; 15 (6-7): 333-41.

4. Filho FL, Tatagiba M, Carvalho GA, Weichhold W, Klekamp J, Samii M. Neurenteric cyst of the craniocervical junction. Report of three cases. J Neurosurg. 2001; 94Suppl 1: 129-32.

5. Eynon-Lewis NJ, Kitchen N, Scaravilli F, Brookes GB. Neurenteric cyst of the cerebellopontine angle: case report. Neurosurgery. 1998; 42(3): 655-8.

6. Tuzun Y, Izci Y, Sengul G, Erdogan F, Suma S. Neurenteric cyst of the upper cervical spine: excision via posterior approach. Pediatr Neurosurg. 2006; 42 (1): 54-6.

7. Masatoshi Y, Koji H, Yuji G, Kimihiro Y, Shunichiro F, Koichi M. True intraspinal neurenteric cyst in the lumbosacral region: case report. Neurol Med Chir. 2007; 47(5): 237-9.

8. Korinth MC, Muller HD, Gilsbach JM. Neurenteric cyst of the cervical spine with mediastinal extension. Case illustration. J Neurosurg Spine. 2003; 98Suppl 1: 112.

9. Kumar R, Nayak SR. Unusual neuroenteric cysts: diagnosis and management. Pediatr Neurosurg. 2002; 37 (6): 321-30.

10. Shenoy SN, Raja A. Spinal neurenteric cyst. Report of 4 cases and review of the literature. Pediatr Neurosurg. 2004; 40 (6): 284-92.

11. Prasad VS, Reddy DR, Murty JM. Cervico-thoracic neurenteric cyst: clinicoradiological correlation with embryogenesis. Childs Nerv Syst. 1996; 12 (1): 48-51

12. Holmes GL, Trader S, Ignatiadis P. Intraspinal enterogenous cysts. A case report and review of pediatric cases in the literature. Am J Dis Child. 1978; 132 (9): 906-8.

13. Lonjon M, Paquis P, Michiels JF, Griffet J, Grellier P. Endodermal cyst of the foramen magnum: case report and review of the literature. Childs Nerv Syst. 1998; 14(3): 100-3.

14. Sarnat, HB. Disorder of maturational processes. In: Sarnat HB, editor. Cerebral dysgenesis embryology and clinical expression. New York: Oxford University Press; 1992. p. 100-02.

15. Fortuna A, Mercuri S. Intradural spinal cysts. Acta Neurochir (Wien). 1983; 68 (3-4): 289-314.

16. Lippman CR, Arginteanu M, Purohit D, Naidich TP, Camins MB. Intramedullary neurenteric cysts of spine: case report and review of the literature. J Neurosurg. 2001; 94Suppl 2: 305-9.

17. Kadhim H, Proano PG, Saint MC, Boscherini D, Clapuyt P, Godfraind C, et al. Spinal neurenteric cysts presenting in infancy with chronic fever and acute myelopathy. Neurology. 2000, 54(10): 2011-5.
18. Paolini S, Ciappetta P, Domenicucci M, Guiducci A. Intramedullary neurenteric cyst with a false mural nodule. Case report. Neurosurgery. 2003; 52(1): 243-6.

19. Brooks BS, Duvall ER, el Gammal T, Garcia JH, Gupta KL, Kapila A. Neuroimaging features of neurenteric cysts: analysis of nine cases and review of the literature. AJNR Am J Neuroradiol. 1993; 14(3): 735-46.

20. Reddy DR, Reddy C, Prasad V, Prasad K. Neurenteric cyst. Neurol India. 1994; 42(2): 114-5.

21. Shetty A, Raja A. Dorsal spinal entergonenous cyst. A case report and review of literature. Neurol India. 1998(4); 46: 300-2.

22. Vinters HV, Gilbert JJ. Neurenteric cysts of the spinal cord mimicking multiple sclerosis. Can J Neurol Sci. 1981; 8(2): $159-61$.

23. Oyama H, Ikeda A, Inoue S, Nakamura S, Nishimura Y, Shibuya M. Multiple neurenteric cysts in the posterior fossa and cervical spinal canal-case report. Neurol Med Chir (Tokyo) 2004; 44(3):146-9.

24. Midha R, Gray B, Becker L, Drake J. Delayed myelopathy after trivial neck injury in a patient with a cervical neurenteric cyst. Can J Neurol Sci. 1995; 22(2): 168-71.

25. Devkota UP, Lam JM, Ng H, Poon WS. An anterior intradural neurenteric cyst of the cervical spine: complete excision through central corpectomy approach - case report. Neurosurgery. 1994; 35(6): 1150-4.

26. Menezes AH, Ryken TC. Craniocervical intradural neurenteric cysts. Pediatr Neurosurg. 1995; 22 (2): 88-95.

27. Mann KS, Khosla VK, Gulati DR, Malik AK. Spinal neurenteric cyst. Association with vertebral anomalies, diastematomyelia, dorsal fistula, and lipoma. Surg Neurol. 1984; 21(4): 358-62.

28. Tubbs RS, Salter EG, Oakes WJ. Neurenteric cyst: case report and a review of the potential dysembryology. Clin Anat. 2006; 19(7): $669-72$

29. Hayashi Y, Tachibana O, Muramatsu N, Tsuchiya H, Tada M, Arakawa Y, et al. Rathke cleft cyst: MR and biomedical analysis of cyst content. J Comput Assist Tomogr. 1999; 23(1): 34-8.

30. Preece MT, Osborn AG, Chin SS, Smirniotopoulos JG. Intracranial neurenteric cysts: imaging and pathology spectrum. AJNR Am J Neuroradiol. 2006; 27(6): 1211-6.

31. Wilkins RH, Odom GL. Spinal intradural cysts. In: Vinken PJ, Bryn GW, editors. Handbook of clinical neurology. New York: North Holand Publishing Co; 1976. p. 55-102.

32. Chavda SV, Davies AM, Cassar-Pullicino VN. Enterogenous cysts of central nervous system: report of eight cases. Clin Radiol. 1985; 36(3): 245-51.

33. Krings T, Lukas R, Reul J, Spetzger U, Reinges MH, Gilsbach JM, et al. Diagnostic and therapeutic management of spinal arachnoid cysts. Acta Neurochir (Wien). 2001; 143(3): 227-35. 